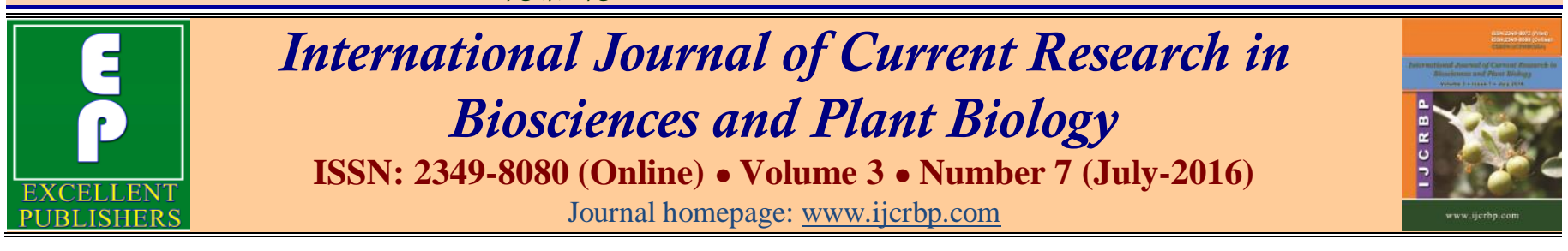

Original Research Article

doi: $\underline{\text { http://dx.doi.org/10.20546/ijerbp.2016.307.011 }}$

\title{
The Ecological Distribution of Wild Prumus africana in Mount Cameroon National Park, Cameroon
}

\author{
E. M. Melle*, A. F. Nkwatoh and R. A. Nsadzetsen \\ Department of Environmental Science, Faculty of science, University of Buea, Cameroon \\ *Corresponding author.
}

\begin{abstract}
Tropical montane forests contain some of the world's richest plant communities but knowledge of the population and distribution of their diversity is still fragmentary. Among such species is Prunus africana which is of great economic and health value to forest communities and the world at large. The aim of the study was to evaluate the abundance, pattern of distribution, bark thickness and health status of Prunus Africana along elevational gradient on the slopes of mount Cameroon. In this study, three classes of elevations (1700 -2000m, 2000-3000m and 3000m and above) were selected using a digitized map of mount Cameroon and a global positioning receptor (Garmin GPSMAP 60CX). Sampling plots were selected in three different blocks of the mountain using management inventory method under adaptive cluster sampling technique. Five square plots measuring $100 \mathrm{~m}$ by $100 \mathrm{~m}$ were examined in three different classes of elevation. In each plot, record of all Prunus trees, diameter at breast height, bark thickness and health status were examined. ANOVA, Correlation, and Chi-square were the statistical models used in the data analysis. The result showed that a total number of 177 trees were recorded from the entire national park surface area $\left(450,000 \mathrm{~m}^{2}\right)$. The height density $(6.2$ stem/ha) was recorded at the lowest class of elevation while the least density $(1.2$ $\mathrm{stem} / \mathrm{ha}$ ) was recorded at the highest class of elevation. It also revealed that variations in elevation accounted for $0.001 \mathrm{~cm}$ change in bark thickness. The highest mean bark thickness $(1.12 \mathrm{~cm})$ was recorded at the highest class of elevation while the least mean bark thickness $(0.86 \mathrm{~cm})$ was recorded at the least elevation. The highest mean diameter at breast height $(51.22 \mathrm{~cm})$ was registered at the highest class of elevation while the least mean diameter at breast height $(36.57 \mathrm{~cm})$ was recorded at the lowest class of elevation. Healthy trees had the highest population $(83.87 \%)$ at the lowest class of elevation while the least population $(61.11 \%)$ was found at the highest class of elevation.
\end{abstract}

\section{Introduction}

The management of natural forests in Sub Saharan Africa is constrained by limited understanding of the state, conditions and distribution of these forests in terms of structure, composition, natural regeneration and quantitative evaluation of tangible and intangible benefits. Prunus africana, formerly known as Pygeum
Article Info

Accepted: 15 June 2016

Available Online: 06 July 2016

Keywords

Mount Cameroon National Park Natural forests

Plant communities

Prunus africana africanum, belongs to the family Rosaceae (Stewart, 2003). It is the only Prunus species indigenous to mainland tropical Africa (Cunningham et al., 1997). It is a geographically widespread forest tree species restricted to afromontane forest which are generally above $1,000 \mathrm{~m}$ in altitude (Cunningham and Mbenkum, 1993). The tree is also known as African Cherry or Red Stinkwood and grows up to $30 \mathrm{~m}$ tall and can reach a diameter at breast 
height of $1.5 \mathrm{~m}$. It is a light demanding and a secondary forest canopy tree species with thick barks. In West African, the largest population of Prunus is found in Cameroon where it has been recorded in about 24 different sites, most of which fall within the Cameroon Volcanic Line that stretches from Mount Cameroon in the Gulf of Guinea to Tchabal Mbabo area in the Adamaoua plateau. Commercial exploitation of Prunus africana bark started effectively in Western and Northwest region of Cameroon in 1972 and extended in less than half a decade to the Mount Cameroon region in the South-west region. Cameroon has been the leading exporter of Prunus africana bark to international markets, providing $2 / 3$ of international demand and on average $40 \%$ of world exports over the last 40 years (Ingram et al., 2009; Cunningham and Mbenkum, 1993). Cameroon is one of the major resources of all parts of Prunus africana (Barks 29\%, 31\% extract, 34\% powder and $6 \%$ derivatives and $1 \%$ dried plants from 2000 to 2007. In local communities in Cameroon and elsewhere, the hard and durable wood of Prunus africana make it a favourite for domestic purposes (ICRAF, 1994). A growing demand could thus be placed on fewer resources, hence threatening those Prunus africana trees within conservation areas. Several independent inventories have been carried out to determine the population size and distribution of Prunus africana in Cameroon. The recent inventory carried out by the Centre for International Forestry Research (CIFOR) together with other research organizations demonstrated that the species is concentrated in the dense tropical submontane and montane mixed forests of the South-west region especially Manenguomba, kuope area, and mount Cameroon and North-west regions of Cameroon where it is concentrated around Bamenda, Fundong, Kumbo, Ndu and Oku areas (Ingram et al., 2009).

However, in Mount Cameroon National Park, several inventories and studies have been carried out on distribution and management of Prunus. Result confirmed continuous decline of Prunus population in these region due to inadequate harvesting techniques and overexploitation. This has resulted to Prunus africana being placed under Appendix II of Convention on Trade in Endangered Species (CITES), which allows for regulated trade under permit. However to fulfill the obligation as a CITES signatory country, the government have to provide a management plan to ensure the sustainability of the species (Ingram et al., 2009). The present research on evaluating Prunus africana population, distribution and bark thickness along elevational gradient in Mount Cameroon National Park is part of the process to ensure a sustainable management of the species within the area. This is because the data obtained during this research can be very important in setting exploitation quotas

Tropical montane forests are highly threatened ecosystems with rapidly declining surface area, species abundance and composition (Gentry, 1995). They are also the least studied and most threatened of all tropical vegetation types. Mount Cameroon is one of the biodiversity hotspot in the world, harbouring important plants and animal species of global importance. Mount Cameroon National Park created by Decree No. 2009/2272/PM on the $18^{\text {th }}$ December 2009 and classified under IUCN Category II protected areas is exceedingly rich in Prunus Africana species. But it is rather unfortunately that information on species population, distribution and bark thickness is not sufficient. Therefore, conservation and sustainable management strategy of Prunus in the Park will not be feasible without a full knowledge of population of the species, it distribution base on DBH along elevational gradients and bark thickness on slopes of Mount Cameroon. Prunus is one of the species that brings income both at the local and national level. The high medicinal value (production of drugs use for the treatment of prostate cancer in men) and other uses such as timber processing and fuel wood provision make Prunus a very important tree species. Considering the fact that knowledge on the distribution and abundance of this species is limited and there is likelihood that the species may become extinct if sustainable management measures are not taken is a cause for concern(CITES, 2006).It is imperative therefore that evaluating Prunus africana population, distribution and bark thickness along elevational gradients in Mount Cameroon is of great importance as it will provide reliable data for proper planning, conserving and management of the species on Mount Cameroon.

\section{Materials and methods}

\section{Description of the study area}

Mount Cameroon belongs to the Cameroon Volcanic Line (CVL), a major structural feature in Central Africa, characterized by the alignment of continental volcanoes, plutons and oceanic volcanic islands, Bioko, Principe, Sao Tomé, Pagalu, (Fitton et al., 1983). It is situated between lomgitude $9^{\circ} 16^{\prime} \mathrm{E}$ and latitude $4^{\circ} 9^{\prime} \mathrm{N}$. Morphologically, Mount Cameroon is a strato volcano, situated on a horst with boundary faults that are expressed by breaks of slopes. It is bounded by the 
Tombel graben to the North and the Douala basin to the South. The climate of the Mount Cameroon region is characterised by its seasonal nature. The seasons are very well defined. There is a period of heavy rains occurring between the months of April and October, and a dry period extending from November to February. Hence there are basically two seasonal periods; the dry and raining seasons (Payton, 1993). At lower altitude, the annual rainfall ranges from about $10,000 \mathrm{~mm}$ at Cape Debundscha to less than $2,000 \mathrm{~mm}$ in the north-east of the massif around Munyenge Metombe. Mean annual rainfall decreases with altitude to approximately 4,000 $\mathrm{mm}$ at $1000 \mathrm{~m}$ and to less than $3,000 \mathrm{~mm}$ above $2,000 \mathrm{~m}$
(Payton, 1993). The main annual rainfall of the area varies between $2085 \mathrm{~mm}$ near Ekona to $9086 \mathrm{~mm}$ at Debundscha (Fraser et al., 1998). The mean monthly temperature, at sea level, varies from 19 to $30^{\circ} \mathrm{C}$ with the maximum in March-April (Fraser et al., 1998).

The mean annual temperature is about $25^{\circ} \mathrm{C}$ and this decreases by $0.6^{\circ} \mathrm{C}$ per $100 \mathrm{~m}$ of ascent, to $4^{\circ} \mathrm{C}$ at the summit (Boughey, 1955). Payton (1993) points out that the humidity of Mount Cameroon is between $75-85 \%$ due to the marine influence and cloud formation. Fig. 1 depicts the map of the study area, Mount Cameroon National Park.

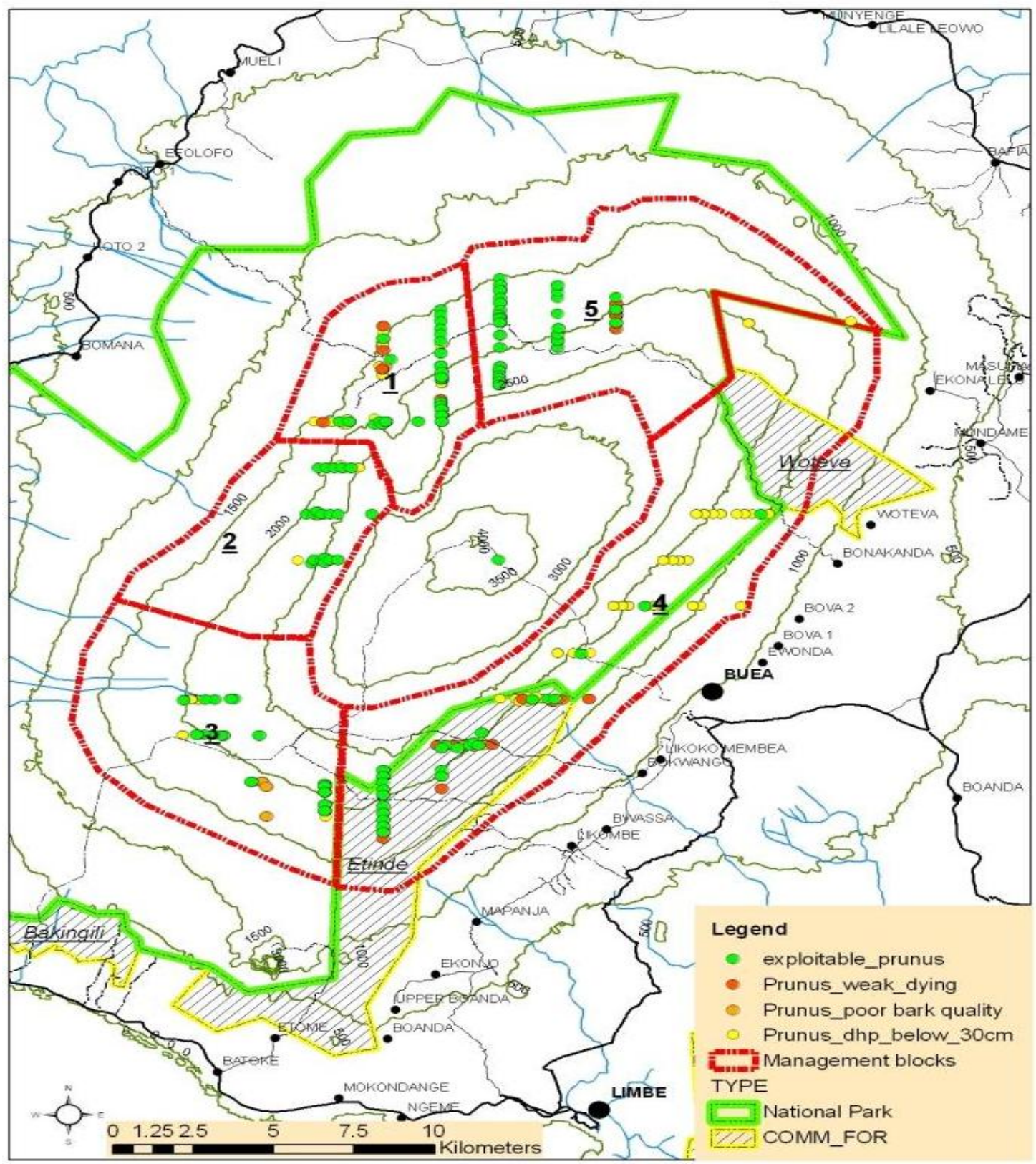

Fig. 1: Map of the study area, Mount Cameroon National Park (Source: Ndam, 1996). 


\section{Data collection}

Before carrying out this field work, the Regional Delegation of Forestry and Wildlife, Mount Cameroon National Park authorities, chief of Bokwango, and Bonakanda were consulted to have their approval, permission and participation in the research work. The services of the villagers within these communities were needed as they were very instrumental in the realization of the field work, since potters and guides came from the villages. The national park was divided into five blocks to ensure the sustainable management of Prunus africana. However, the study was done in block one, two, three and four. Intensive field work was done more in block two, three and four in May, June and July 2015 respectively. Sampling was done using management inventory technique, such as the adaptive cluster sampling method, which is more efficient for gregarious specie. Transects were made in three areas of elevation ([1700-2000m, 2000-2300m, and 2300-2600m) in all the blocks. These transects were one $\mathrm{km}$ in length. More five square plots measuring $100 \times 100 \mathrm{~m}^{2}$ were made at each elevation in all the blocks. At the end of field exercise 45 plots were examined all covering a total surface area of $450,000 \mathrm{~m}^{2}$ with a total number of 177 Prunus africana trees recorded. The identification of trees was done in the field using a combination of techniques, such as the general form of the tree (bark texture; slash colour, smell, exudates, buttresses, leaf type and shape) as well as the flowers, and fruits of the trees. Tree structural data were collected and recorded in each plot using a datasheet file.

The tree health was assessed by considering the presence of parasites such as the Loranthus species, predators such as xylophagous and phytophagous insects (Lepidoptera caterpillar, Celeoterous borers, Amphid) and Rodent which feed on Prunus africana. This is generally indicated by crown health (Nsom et al., 2007). However, in this work, trees that were considered healthy were without dried branches, no insects, rodents or parasites attacks, while unhealthy trees were those with death / dried branches.

Tree basal area, bark thickness and DBH class sizes were compared between different elevations within the study area using measures of central tendency (ANOVA). Tree densities along elevation were calculated using standard formula. Correlation and regression statistical models were used to test the relationship between variables at different elevation. Analyses were done using MINITAB 17 software. The following basic calculations were employed.

\section{Results}

A total of 177 trees were recorded on a total surface area of $450,000 \mathrm{~m}^{2}$ (45 hectare) on the slopes of Mount Cameroon. Table 1 below shows the distribution of tree density in different areas of elevation. The highest density of 6.2 (stem/ha) was recorded at the lowest area of elevation [1700-2000m] while the least density of 1.2 (stem/ha) was recorded at the highest area $[2300 \mathrm{~m}$ and above]. However, the average density of the entire study area was 3.9 (stem/ha).

Table 1. Prunus tree densities along elevational gradient on the slopes of Mount Cameroon.

\begin{tabular}{llll}
\hline $\begin{array}{l}\text { Elevation } \\
(\mathbf{m})\end{array}$ & $\begin{array}{l}\text { Number of } \\
\text { trees }\end{array}$ & $\begin{array}{l}\text { Surface } \\
\text { area(ha) }\end{array}$ & $\begin{array}{l}\text { Tree density } \\
\text { (No. of } \\
\text { stem/ha) }\end{array}$ \\
\hline$>2300$ & 18 & 15 & 1.2 \\
{$[2000-2300]$} & 65 & 15 & 4.3 \\
{$[1700-2000]$} & 93 & 15 & 6.2 \\
\hline
\end{tabular}

The Mean Tree Basal Area (TBA) from table 2 below shows a gradual increase with increase elevation. The least mean TBA $\left(820.7 \mathrm{~m}^{2} / \mathrm{ha}\right)$ was recorded at the lowest class of elevation [1700-2000 m] while the highest mean TBA $\left(1565.3 \mathrm{~m}^{2} / \mathrm{ha}\right)$ was recorded at the highest class of elevation [2300m and above]. There was no significance difference in the mean TBA recorded at elevational classes of $[2000-2300 \mathrm{~m}]$ and $[2300 \mathrm{~m}$ and above] while mean TBA at lower class of elevation [1700-2000m] was highly significant.

Table 2. Variation in Mean Tree Basal Area (TBA) along elevational gradient on Mount Cameroon.

\begin{tabular}{ll}
\hline Elevation $(\mathbf{m})$ & Mean $\mathbf{T B A}\left(\mathbf{m}^{2} / \mathbf{h a}\right)$ \\
\hline$>2300$ & $1565.3 \mathrm{a}$ \\
{$[2000-2300]$} & $1145.2 \mathrm{a}$ \\
{$[1700-2000]$} & $820.7 \mathrm{~b}$ \\
\hline$p=0.006(\mathrm{~F}=28.1)$ by Kruskal-Walis rank test.
\end{tabular}

Tree diameter at breast height shows variations along elevations of mount Cameroon. Table 3 below indicates increase in mean DBH with increase elevation. The lowest mean DBH $(36.57 \mathrm{~cm})$ was recorded at the lowest class of elevation [1700-2000m] and the highest mean DBH $(51.22 \mathrm{~cm})$ was recorded at the highest class of elevation $[2300 \mathrm{~m}$ and above]. There was a significant difference in mean DBH recorded at the lowest class of elevation while there was no significant difference in mean DBH recorded at the other two classes of elevation. 
Table 3. Mean DBH $(\mathrm{cm})$ along elevations on the slopes of Mount Cameroon.

\begin{tabular}{ll}
\hline Elevation $(\mathbf{m})$ & Mean DBH $(\mathbf{c m})$ \\
\hline$>2300$ & $51.22 \mathrm{a}$ \\
{$[2000-2300]$} & $44.34 \mathrm{a}$ \\
{$[1700-2000]$} & $36.57 \mathrm{~b}$ \\
\hline
\end{tabular}

$p<0.02(\mathrm{~F}=40.6)$ by Kruskal-Walis rank test.

From Table 4 below, Mean Bark thickness of trees for Non-exploited sides recorded the highest mean values while the exploited sides had the least mean values along all the elevational classes. For Non-exploited sides, there was a gradual increase in mean bark thickness with increase elevation. The least mean bark thickness $(0.86 \pm 0.2 \mathrm{~cm})$ was recorded at the lowest class of elevation [1700-2000m], while the highest mean bark thickness $(1.12 \pm 0.4 \mathrm{~cm})$ was recorded at the highest class of elevation [2300m and above]. For exploited sides, there was an irregular variation in mean bark thickness along elevation. The highest mean bark thickness recorded was $(0.428 \pm 0.03 \mathrm{~cm})$ at elevational class range $[2000-2300 \mathrm{~m}]$ and the least recorded was $(0.39 \pm 0.02 \mathrm{~cm})$ at lowest class of elevation [1700-2000 m].

Table 4. Comparison/distribution of mean bark thickness $(\mathrm{cm})$ along elevations in exploited and non-exploited sides of trees.

\begin{tabular}{lll}
\hline \multirow{2}{*}{ Elevation $(\mathbf{m})$} & \multicolumn{3}{l}{ Mean bark thickness $(\mathbf{c m})$} \\
\cline { 2 - 3 } & Exploited side & Non-exploited side \\
\hline$[1700-2000]$ & $0.189 \pm 0.01 \mathrm{~b}$ & $1.12 \pm 0.4 \mathrm{a}$ \\
{$[2000-2300]$} & $0.428 \pm 0.03 \mathrm{a}$ & $1.06 \pm 0.3 \mathrm{a}$ \\
$>2300$ & $0.139 \pm 0.02 \mathrm{~b}$ & $0.86 \pm 0.2 \mathrm{~b}$ \\
\hline$p<0.001(\mathrm{~F}=53.4)$ by Kruskal-Walis rank test.
\end{tabular}

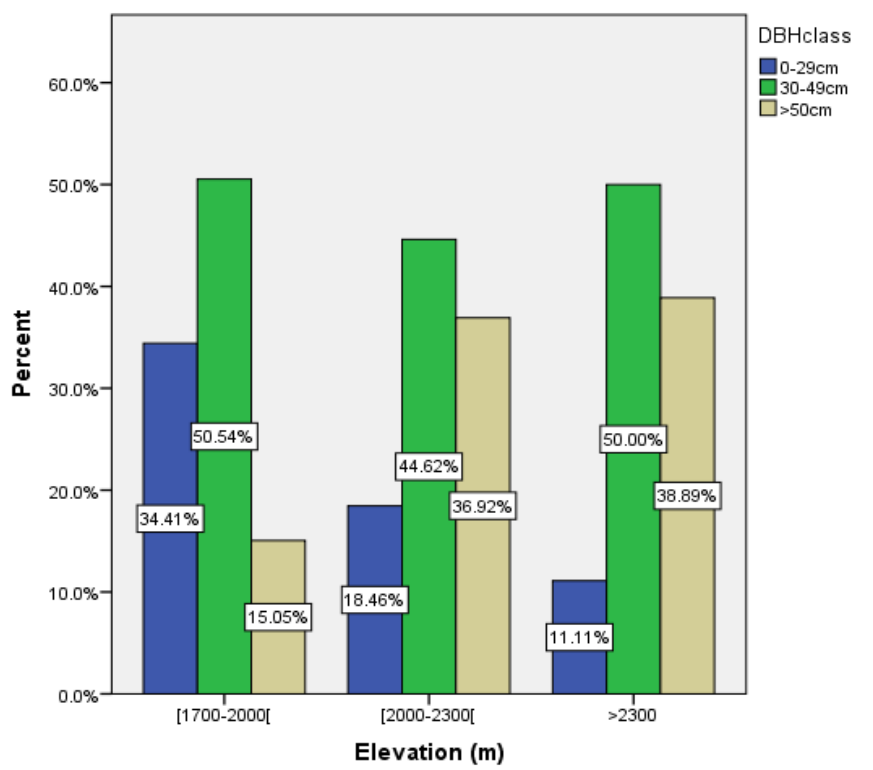

Fig. 2: DBH class distribution along elevational gradient on mount Cameroon.
Trees with DBH class $(0-29 \mathrm{~cm})$ showed a gradual decrease in population with increase elevation. They had the highest percentage $(34.41 \%)$ at the lowest class of elevation [1700-2000], and the least population (11.11\%) at the highest elevation. At DBH size class of $50 \mathrm{~cm}$ and above, there was a gradual increase in population with increase elevation with the lowest class of elevation [1700-2000m], having $15.05 \%$ of population and the highest class of elevation [2300m and above], having $38.89 \%$ of population. The third DBH size class (30$49 \mathrm{~cm}$ ) varies irregularly with elevation where the lowest and highest elevational class ranges had $50.54 \%$ and $50 \%$ of population respectively.

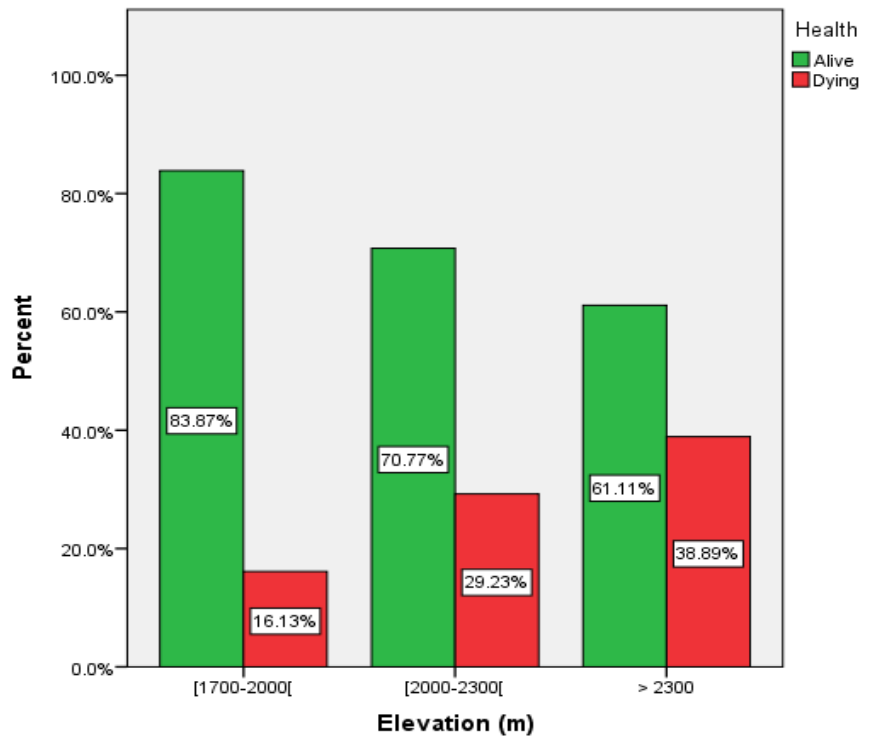

Fig. 3: Comparison of tree health along elevational gradient on Mount Cameroon. $p=0.04$ (Chi square value $=6.4, \mathrm{df}=2$ ).

From Fig. 3 above, live trees had the highest population $(83.87 \%)$ recorded at the lowest class of elevation [1700$2000 \mathrm{~m}$ ] and the least population $(61.11 \%)$ recorded at the highest class of elevation [2300m and above]. Dying trees had the least population $(16.13 \%)$ found at the lowest class of elevation [1700-2000m] and the highest population $(38.89 \%)$ found at highest class of elevation [2300m and above].

From Fig. 4, healthy trees had the highest population $(81.18 \%)$ found in DBH size class $30-49 \mathrm{~cm}$ while the least population $(71.11 \%)$ was recorded at $\mathrm{DBH}$ size class $50 \mathrm{~cm}$ and above. For the unhealthy trees, their population in all DBH size classes was not significant. However the highest number of tree $(28.89 \%)$ was recorded at $\mathrm{DBH}$ size class $50 \mathrm{~cm}$ and above while the least population (18.92\%) was found in DBH size class $30-49 \mathrm{~cm}$. 


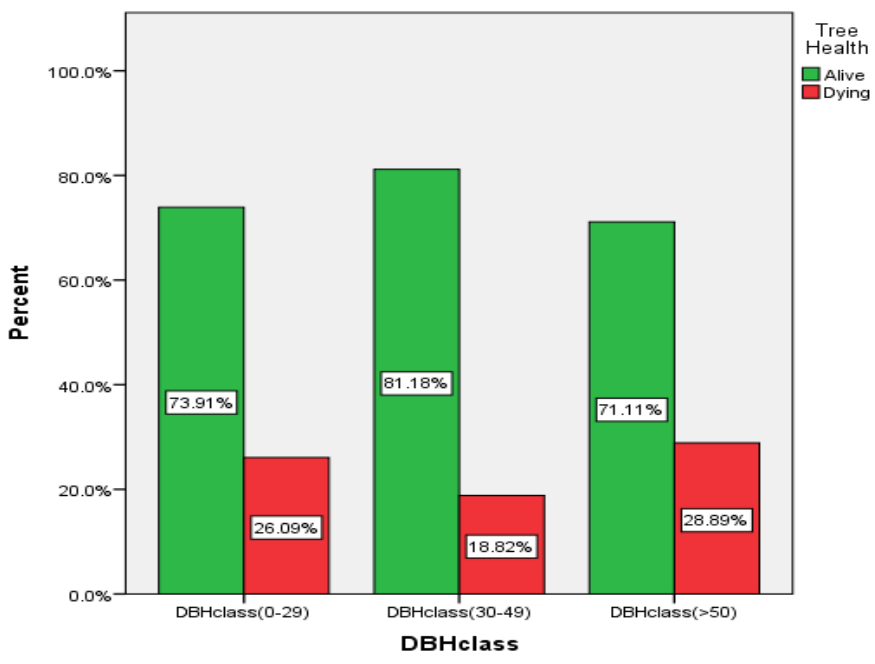

Fig. 4: Variation in tree health per DBH size classes on Mount Cameroon. $p=0.365$ (Chi-Square value $=1.95, \mathrm{df}=2$ ).

\section{Discussion}

\section{Tree densities along elevational gradient of Mount Cameroon}

Generally across the slopes of Mount Cameroon, Prunus densities decrease with increase elevation. From the studies, the result showed the highest tree density of 6.2 stem/ha at the lowest class of elevation and the least density of 1.2 stem/ha at the highest class of elevation (Table 1). In these studies, the class of elevation where the highest density of trees was recorded fall within the forest structure called upper montane rain forest/sub-alpine rain forest which is characterized by discontinuous canopy, few species, open forest, and with Prunus being the common species. For the least stem density recorded, this is explain by the fact that this class of elevation fall within the forest type known as montane grassland/ sub alpine grassland which is characterized by species poor, tussock grasses, dwarf trees and scattered fire resistance trees including Prunus. However, the average tree density for the entire mount Cameroon area was $3.9 \mathrm{stem} / \mathrm{ha}$. This differs from the result of (Ingram et al., 2009) carried out in the same region which proposed a density of 3.52 stem/ha. The reason for these variations is based on methods of forest inventory where Ingram et al. (2009) used $100 \%$ inventory under ACS method while the work make used of management inventory under ACS method.

Tree barks thickness in exploited and Non-exploited sides along elevational gradient

Across elevational gradient on the slopes of Mount Cameroon, Prunus barks thickness for Non-exploited sides of trees increase with increase elevation. From these studies the highest mean bark thickness $1.12 \mathrm{~cm}$ was recorded at the highest elevation while the least bark thickness $0.86 \mathrm{~cm}$ was recorded at the lowest class of elevation (Table 4). The reason for these variations along elevation is as a result of both natural and human environmental adaptations. That is, thick barks to protect against savanna yearly wild fire and to preserve water in rainy seasons which can sustain the tree in dry season since soils in mount Cameroon are porous. This result correspond with the findings of Belinga (2001) who concluded that bark thickness on the slopes of Mount Cameroon varies both with ecology, age and size of the tree. However bark thickness for exploited sides of trees showed irregular variation (Table 4). This is due to differences in exploitation periods of these trees while some are constantly exploited because easy access.

\section{Population distribution base on DBH size class along elevational gradients}

The distribution of Prunus by (DBH) size class along elevational gradient on mount Cameroon showed different variations. Trees with DBH class $(0-29 \mathrm{~cm})$, that is, young trees showed a gradual decrease in population with increase elevation. The highest population (34.41\%) was recorded at the lowest class of elevation and least population (11.11\%) was recorded at the highest class of elevation. At DBH size class of $50 \mathrm{~cm}$ and above, that is, larger trees there was a gradual increase in population with increase elevation with the lowest class of elevation having $15.05 \%$ of population and the highest class of elevation has $38.89 \%$ of population (Fig. 4). This is attributed to unsustainable exploitation (ring debarking and felling of trees) by illegal exploiters since lower elevations are closer to communities around Mount Cameroon than higher elevations, thus there is easy access to this lower elevation forest. This reduces the population of larger trees and increases that of smaller trees at lower elevations and vice versa. Also, young trees are more at lower elevation due to the fact that the environmental conditions prevailing at higher elevation do not favour young plants.

\section{Tree health along elevational gradient}

From the result, there was a regular variation in both live and dying trees along elevations (figure 4). Live trees showed gradual and steady decrease in population with increase elevation with the highest population $(83.87 \%)$ recorded at the lowest class of elevation [1700-2000m] and the least population $(61.11 \%)$ recorded at the highest 
class of elevation [2300m and above]. Dying trees showed steady increase in population with increase elevation with the least population $(16.13 \%)$ found at the lowest class of elevation [1700-2000m] and the highest population $(38.89 \%)$ found at highest class of elevation [2300m and above]. High population of dying trees at higher elevation is explain by the fact that most trees are exposed to adverse environmental conditions such as lack of water, wild fire and rodent attacked. High population of life tree at lower elevation was as a result re-aforestation, Agroforestry and conducive environmental conditions that favours the growth of Prunus. These results ties with those of Nkeng (2009). Higher population for live trees and lower population for dying trees in all the classes of elevation are because most trees are young and more able to withstand over exploitation while larger trees are more vulnerable. These findings correspond to those of Nkeng (2009).

\section{Tree mean DBH variation along elevation}

From Table 2, DBH increase with increase elevation with the lowest DBH $(36.57 \mathrm{~cm})$ at the lowest class of elevation and the highest DBH $(51.22 \mathrm{~cm})$ at the highest class of elevation. This indirectly implies that at lower elevations there are more young trees than larger trees while at higher elevations there are larger trees than younger trees. This disparity is due to unsustainable/over exploitation of larger trees since lower elevation is closer to communities than higher elevations. Also young trees have high resistance to harsh conditions and recover easily from exploitation. This finding confirms the results of Stewart (2009) who highlighted similar finding in Kilum forest.

\section{Conclusion and recommendations}

This survey has shown that Prunus densities decrease with increase elevation with the highest density of 6.2 stems/ha at lower elevation and least density of 1.2 stems/ha at higher elevation. However, the average density for Mount Cameroon area was $3.9 \mathrm{stem} / \mathrm{ha}$. The mean bark thickness for Non-exploited sides increase with increase elevation with $0.001 \mathrm{~cm}$ increase in bark thickness accounted for by changes in elevation. Thus highest density $(1.12 \mathrm{~cm})$ was recorded at higher elevation and least $(0.86 \mathrm{~cm})$ recorded at lower elevation. Also the trees with DBH size $0-29 \mathrm{~cm}$ (young trees) decrease with increase elevation with highest population of $(34.41 \%)$ at lower elevation and least population $(11.11 \%)$ at the highest elevation. The trees with DBH above $50 \mathrm{~cm}$ (large trees) increase in population with increase elevation, with the highest population (38.89\%) at higher elevation and the least population $(15.05 \%)$ at lower elevation. Therefore, there are younger trees at lower elevation than at higher elevation and vice versa. The healthy trees decrease in population with increase elevation with the highest population of $(83.87 \%)$ at lower elevation and the least population $(61.11 \%)$ at higher elevation. But the unhealthy trees increase in population with increase elevation with the highest population $(38.89 \%)$ at higher elevation and least population (16.13\%) at lower elevation. Also majority of dying trees are those with larger $\mathrm{DBH}(50 \mathrm{~cm}$ and above).

Hence, more studies should be carried out on chemical analysis of the constituent elements in Prunus extract from different elevational gradients of the slopes of mount Cameroon to determine whether variations in elevation affect the chemical composition of Prunus. Furthermore, research should be carried out on the bark regeneration rate of exploited trees to sustainably manage Prunus.

\section{Conflict of interest statement}

Authors declare that they have no conflict of interest.

\section{References}

Belinga, S. J., 2001. Rapport D'inventaire National Du Prunus africana. Phase 2 Adamaoua, Tchabal Mbabo, Tchabal Gang Daba Forets, M. d. 1. e. d. Office National de Développement des Forets. 91p.

Boughey, A. S., 1955. The vegetation of the mountain of Biafra. Proc. Linn. Soc. 165, 144 -150.

CITES, 2006. Review of Significant Trade in Specimens of Appendix-II Species. Species Selected Following COP11 and COP12. CITES Sixteenth Meeting of the Plants Committee, Lima, Peru.

Cunningham, A. B., Mbenkum, F. T., 1993. Sustainability of harvesting Prunus africana bark in Cameroon. A medicinal plant in international trade. People Plants Working Paper. 2, 1-32.

Cunningham, M., Cunningham, A. B., Schippmann, U., 1997. Trade in Prunus africana and the Implementation of CITES. German Federal Agency for Nature Conservation, Bonn, Germany.

Fitton, J. G., Kiburn, C. R. J., Thiriwall, M. F., Hughes, D. J., 1983. 1982 Eruption of Mount Cameroon, West Africa. Nature. 306(594), 327-332.

Fraser, P. J., Hall, J. B., Healey, J. R., 1998. Climate of the Mount Cameroon Region, Long and Medium Term Rainfall, Temperature and Sunshine Data. SAFS, University of Wales, Bangor, MCPLBG, Limbe. p.56. 
Gentry, A. H., 1995. Patterns of diversity and floristic composition in neotropical montane forests. In: Biodiversity and Conservation of Neotropical Montane Forests (Eds.: Churchill, S. P., Balslev, H., Forero, E., Luteyn, J. L.). The New York Botanical Garden, Bronx, New York. pp.103-126.

ICRAF, 1994. Agroforestry Extended Manual for Kenya. Published by ICRAF, UN Avenue, Gigiri P.O. Box 30677, Nairobi, Kenya.

Ingram, V., Awono, A., Schure, J., Ndam, N., 2009. National Prunus africana Management Plan for Cameroon, CIFOR, Yaounde. 156p.

Ndam, N., 1996. Recruitment patterns of Prunus africana (Hook f.) Kalkman on Mount Cameroon: A case study at Mapanja. In: A Strategy for the Conservation of Prunus africana on Mount Cameroon. Technical Papers and Workshop Proceedings. February 21-22.

Nkeng, P. F., 2009. Assessment of Prunus africana bark exploitation methods and sustainable exploitation in the South west, North-West and Adamaoua regions of Cameroon. Project GCP/RAF/408/EC: Mobilisation et
Renforcement des Capacités des Petites et Moyennes Entreprises impliquées dans les Filières des Produits Forestiers Non Ligneux en Afrique Centrale. CIFOR, Editor. FAO-CIFOR-SNV-World Agroforestry CenterCOMIFAC, Yaounde. 57p.

Nsom, A., Tah, K., Ingram, V., 2007. Current Situation of Prunus africana in the Kilum Forest Emfveh-Mii and Ijim Community Forests Workshop with Stakeholders on Conflict Resolution in Prunus africana Management, Oku. June 2007, Oku, SNV.

Payton, R. W., 1993. Ecology, Altitudinal Zonation and Conservation of Tropical Rainforest of Mount Cameroon. Final Project Report R4600. ODA, London, Mount Cameroon Project. 70p.

Stewart, K. M., 2003. The African cherry (Prunus Africana): From hoe-handles to the international herb market. Econ. Bot. 57(4), 1-11.

Stewart, K., 2009. Effects of bark harvest and other human activity on populations of the African cherry (Prunus africana) on Mount Oku, Cameroon. Forest Ecol. Manage. 258(7), 1121-1128.

\section{How to cite this article:}

Melle, E. M., Nkwatoh, A. F., Nsadzetsen, R. A., 2016. The ecological distribution of wild Prunus africana in Mount Cameroon National Park, Cameroon. Int. J. Curr. Res. Biosci. Plant Biol. 3(7), 73-80. doi: http://dx.doi.org/10.20546/ijcrbp.2016.307.011 